\title{
The Fragmentary Kinetics of Writing in the Book of Disquiet
}

\author{
Manuel Portela and Diego Giménez
}

\begin{abstract}
In this article we discuss the notion of literary fragment based on Fernando Pessoa's Livro do Desassossego [Book of Disquiet], an unfinished work written between 1913 and 1935. Textual witnesses are analyzed as records of the temporal and kinetic dynamics of writing and rewriting, but also as textual units of a work in progress. Self-consciousness of writing emerges both in autograph textual marks, and in the concept of fragment as a piece of text meant for a bibliographic whole. The fragment becomes a textual unit of composition that links the temporality of script acts to the semantic units of a textual whole that remains elusive and only partially determined. Pessoa's unfinished book project allows us to place this fragmentary logic at the heart of his writing, and see the Book of Disquiet itself as an embodiment of the kinetics of script acts as open explorations of self-consciousness in writing. We address these notions of fragment in the context of our current TEI-XML encoding of both Pessoa's autograph materials and their editorial versions for the LdoD Archive.
\end{abstract}

\section{Introduction}

What is the Book of Disquiet [Livro do Desassossego] by Fernando Pessoa? This is one of the questions that arise when we approach the magnum opus of the Portuguese writer. More than three decades after its first edition (1982), the question continues to be relevant and it goes beyond approaching the work's textual content to raise issues of material integrity, that is, questions about autograph witnesses supporting the various editions of the Book and their interpretations for deciphering, selecting and organizing Pessoa's fragmentary writing. When analyzing the fragmentary Woyzeck by Georg Büchner, Dedner Burghard writes that in such works the saying "the whole is more than the sum of its parts" does not apply, and he goes on to add "these conceptually different fragmentary pieces do not add up to one whole at all, a fact which will sadden the dominant school of interpretation, i.e., those who believe in the principle of semantic interdependence between the whole and its parts" (Dedner 2006, 101). 
Dedner's point is especially significant when applied to the Book of Disquiet if we consider that the "whole" that the book represents varies considerably from one edition to another, a divergence that reflects editorial interventions on the autograph sources. Pessoa did not leave a book that was structured as such, despite several plans and his attempts at selecting and ordering its texts and fragments (Sepúlveda 2013). The first edition of the Book, by Jacinto do Prado Coelho (with transcriptions by Teresa Sobral Cunha and Maria Aliete Galhoz), appeared almost fifty years after the writer's death in 1982. This first edition consists of 520 numbered pieces in two volumes. It is organized according to thematic clusters and attributed to Pessoa's heteronym Bernardo Soares ${ }^{1}$. The second edition, by Teresa Sobral Cunha (who had also participated in the transcription and compilation of texts for the first edition), appeared in 1990-91, and consists 724 unnumbered texts arranged chronologically, also in two volumes, which are attributed respectively to heteronyms Vicente Guedes and Bernardo Soares. The third edition, by Richard Zenith, came out in 1998 and consists of 533 numbered pieces organized according to a subjective combination of thematic and chronological criteria. The fourth edition, a critical and genetic edition by Jerónimo Pizarro, came to light in 2010, and includes 586 chronologically arranged and numbered texts and fragments. ${ }^{2}$

1. The first authorial persona for the Livro was Vicente Guedes, but the work was later reassigned by Pessoa to Bernardo Soares, a persona described by Pessoa as a "semi-heteronym". Coelho and Zenith have assigned the Livro to Bernardo Soares; Sobral Cunha has assigned the first part to Guedes and the second to Soares; Pizarro assigns the Livro to Pessoa. A recent version of the Book of Disquiet (2015), edited by Teresa Rita Lopes, assigns 35 fragments to a third heteronym (also referred to by Pessoa as a "semi-heteronym"), Barão de Teive. Although the authorial personae behind Livro do Desassossego tend not to be viewed as full heteronyms, heteronym attribution has been an important function in structuring the work.

2. With the exception of the first edition (reprinted once without changes in 1997), the remaining three critical editions have not yet stabilized. There are now four editions by Teresa Sobral Cunha (1990-91, 1997, 2008, 2013); twelve editions by Richard Zenith (1998, 1999, 2000, 2001, 2003, 2005, 2007, 2009, 2011, 2012, 2013, 2015); and three editions by Jerónimo Pizarro (2010, 2013, 2014). For the past 25 years, critical editors have not managed to publish the work twice under the same textual form. Every reprint becomes an opportunity for introducing further changes and revisions: new readings are offered for particular passages, additional fragments are included while others are excluded, fragments are fused or divided, and a few pieces change place. To these critical 
For Fernando Pessoa "the book" functions as a generative and ideal concept that drives him to produce according to different genres and styles of writing, an ideal form to which his script acts aspire but which he seems unable to close or finish. Those four critical editions conceive of the book in a similar way, that is, as a book that represents an ideal of completeness that is able to collect Pessoa's introspective and daydreaming prose. This ideal of wholeness is associated - whether or not that is the intention of the editors - with the construction of a meaning for both the work and the figure of the author. Conceptual and bibliographic unity expressed as a book has to be mediated by the interpretation of the evidence, which in this case is the evidence of the authorial typescripts and manuscripts in different stages of completion and revision. Hence the assertion by one of the editors that Pessoa has always existed; another editor quotes his heteronym Álvaro de Campos who denies the existence of Pessoa; and a third wonders if Pessoa really existed. Some decide to follow the old spelling used by Pessoa while others decide to modernize it. Three of them title Pessoa's work Livro do Desassossego, and one titles it Livro do Desasocego. The fact remains that the Book of Disquiet cannot be constructed as a book without a strong editorial intervention that codetermines both the whole and its constituent parts.

In this article we discuss what a fragment is in Pessoa's writing in the Book of Disquiet, in order to understand what is specific to those parts of that multiform whole, and also in what ways can this relation of parts to whole be represented in an electronic archive. For that we will start by discussing the four major editions as different forms of critical editing, looking at each editor's prefatory rationale and also at the graphical and bibliographical markers of each critical apparatus. In the third section we will analyze an autograph document for insights about the interactive kinetics of inscribing text on paper, and we will see how textual units of writing often correspond to temporal units of writing. Finally we will discuss the affordances

editing variations in those major editions, we could add many other trade editions in Portugal and Brazil, particularly those published after 2005 when Fernando Pessoa's works came definitively into the public domain. If we further add the translations of the Book of Disquiet, some of which are based on a particular selection and arrangement of fragments by the translators themselves, multiform bibliographic structure and unstable textual form seem to have become defining features of the work itself. There are now several versions of the book in circulation in languages such as Spanish, French, Italian, English, and German, for instance. Pessoa's mental and verbal disquiet has materialized in the posthumous variability of his textual legacy. 
of the digital medium for displaying stages and layers in the genetic archive of Pessoa's fragmentary writing. The encoding of this genetic dimension of the archive is integrated with the encoding of editorial versions, enabling readers to move from authorial fragment to edited fragment to edited book.

\section{Critical editions as textual and bibliographic interventions}

It has been argued that, with the publication of Pizarro's critical-genetic edition in 2010, the editions of $L d o D$ may be divided into two types: the critical and the others. This rather unfair assessment ignores that critical editing can result in different forms of textual display and does not have to be solely identified with the presence of an extensive critical apparatus. Different critical editing strategies have been used by the various editors who have dealt with fragments from Pessoa's work. A critical edition is one that gives the reader access to all textual evidence and explains the rationale through which each particular variant is chosen and interpreted. According to Dedner (2006), this is what distinguishes the scholarly editor from the glossy editor, who does not make explicit the working assumptions for turning textual plurality into a given textual form. While in the first case textual form is shown as the result of editorial interpretation, in the second case the unmarked unity of a clear reading text gives readers a certain degree of illusion about wholeness and stability of form.

In effect, we could argue that these four editions of Book of Disquiet are critical and scholarly editions insofar as they make clear that they are working from a fragmentary and not entirely fixed corpus. Although the extension and detail of the critical apparatus varies considerably in Coelho, Cunha and Zenith, the introductions to each of those editions make explicit their interpretative criteria, such as those that are used for selecting and ordering pieces. Besides presenting the editorial principles for interpreting the work, these critical editions also provide the reader with notes on those pieces of text that show variability and which the editor deems important to make explicit. Finally, a critical genetic edition is one that also shows all textual states during the process of creation and revision. Under these definitions, the editions by Jacinto do Prado Coelho, Teresa Sobral Cunha, and Richard Zenith would qualify as critical editions, while Jerónimo Pizarro's would be a critical genetic edition.

For example, Jacinto do Prado Coelho's edition is a critical edition because it explicitly says in the introduction that the work is ordered according to "thematic clusters", that it presents a reading that is meant 
[1- 71 e 71a, ms.]

$$
\text { L. do } D \text {. }
$$

Coisas de nada, naturaes da vida, insignificancias do usual e do reles, poeira que sublinha com um traço apagado (1) e grotesco a sordidez e a vileza da minha vida humana.

- o Caixa aberto deante dos olhos cuja vida sonha com todos os orientes; a piada inoffensiva do chefe do escriptorio que offende todo o universo; o avisar o patrão que telephone, que é a amiga, por nome e dona [ . ] no meio da meditação do periodo mais in. sexual de uma theoria esthetica e mental.

Todos teem um chefe de escriptorio com a piada sempre inopportuna [?] e a alma fora do universo em seu conjunto. Todos tem um patrăo e a amiga do patrão, e a chamada ao telephone no momento semamantes [...] arriscam falar contra o amigo que está amantes $[\ldots]$ arriscam falar contra o ami
fazendo chi-chi como os outros sabemos.

Mas todos os que sonham, ainda que não sonhem em escriptorios da Baixa, nem deante duma escripta do armazem de fazenda, todos têm um Caixa deante de si - seja a mulher com quem casaram seja a [...] dum futuro que the vem por herança, seja o que for logo que positivamente [?] seja.

Depois os amigos, bons rapazes, bons rapazes, tam agradavel estar fallando com elles, almoçar com elles, jantar com elles, e tudo, não sei como, tam sordido, tam reles, tam pequeno, sempre no armazem de fa. zendas ainda que na rua, sempre deante do livro caixa

(1) fininho/tremidinho ainda que no estrangeiro, sempre com o patrão ainda que no infinito.

Todos nós, que sonhamos e pensamos, somos ajudantes e guarda-livros num Armazem de fazendas, ou de outra qualquer fazenda em uma Baixa qualquer. Escripturamos e perdemos; sommamos e passamos; fechamos o balanço e o saldo invisivel é sempre con tra nos.

Escrevo sorrindo com as palavras, mas o meu coração está como se se pudesse partir (1), partir (1) como as cousas que se quebram, em fragmentos, em cacos, em lixo, que o caixote leva num gesto de por cima dos hombros para o carro do eterno [?] de todas as Camaras Municipais.

E tudo espera, aberto e decorado, o Rei que virá, e já chega, que a poeira do cortejo é uma nova nevo no oriente lento, e as lanças luzem jó na distancia com uma madrugada sua.

\section{A Viagem na Cabeça}

Do meu quarto andar sobre o infinito, no plau sivel intimo da tarde que acontece, à janella para começo das estrellas, meus sonhos vão por accordo de rythmo com distancia exposta para as viagens aos paizes incognitos, ou suppostos ou somente impossiveis $\left({ }^{*}\right)$.

\section{(1) quebrar}

- Os parágrafos dos fragmentos $1-71$ e $1-71$ a encon ram-se na mesma folha dispostos de modo um tanto confus çầo proposta.

O facto da sequencia que colocamos em ulitimo lugar ter titulo próprio não significa, necessariamente, tratar-se do in

130

Figure 1. Transcription and critical apparatus in Coelho for manuscript E3, 1-71-71a. Information about variants and other textual and material features is provided in footnotes (PessoA 1982, 129-130).

neither as the only one nor the best one. This edition uses graphic markers to call attention to variant readings and other textual matters. Thus we have:

/ / Doubts of the Author concerning a word or phrase

( ) Hesitation of the Author as to the desirability of inserting one or more words

(. . .) Passage that was left unfinished by the author

[] Words added by the editors

[. . . Illegible word or phrase

[?] Uncertainty about the offered reading (Pessoa, 1982: XXIX; our translation)

Coelho's edition makes explicit reference to the authorial manuscript and typescript witnesses on which it bases its transcription (Figure 1). In this way one can always refer back a particular transcription to its original source. 
Teresa Sobral Cunha also declares her criteria for selecting and ordering pieces, focusing on two major writing cycles. A first period between 1912 and 1921 is attributed to Pessoa/Guedes, and a second period, between 1928 and 1934, is attributed to Pessoa/Soares. Cunha presents the fragments in chronological order, and she highlights that texts are accompanied by notes whenever they show "significant documentary contingencies [...], separate lists contain the rejected terms and variants". As a result, for this editor:

The discursive body resulting from applying the generic assumptions of this edition - assisted by detecting movements of writing and latent organizational principles that recontextualize primitive cores and enable units of meaning through the gathering of dispersed or loose pieces of text ["trechos"] — seems to settle into a more effective reading .

The editor responsible for this edition is, necessarily, identified with an ordered and cohesive discourse that, by articulating ideation and writing scenes, traces the becoming of the Book of Disquiet, of both the spirit and human profile of him who wrote it and, also, aspects of the community that the historian of his "spiritual reality" chose for the landscape and scenery of this journey through the great "weariness of the soul".

The present edition seems to foreshadow a stronger textual consonance. Even if only approximate to that "only approximately existing" that Fernando Pessoa acknowledged, in the Bibliographic Table of 1928, for other "non- definitive texts". (Cunha in PessoA 2008, 27; our translation)

Interestingly, Cunha explicitly acknowledges her role as an editor who, following certain premises of interpretation, offers a book that is also consistent with an interpretation of the figure of the writer, with his "human profile". This point draws attention to the constraints and responsibilities inherent in the editor's role: should she try to interpret and make sense of the work and figure of the writer and provide readers with an accessible and closed text? Should she respect the plurality of sources and let readers assemble or disassemble the textual puzzle as best they can? The form of her edition suggests that she tried to give the work a stronger graphic and thematic coherence by not numbering the fragments and omitting the national library references. Notes were placed at the end of the volume and textual pieces are separated only by carefully controlled blank spaces, encouraging a more continuous reading experience. Closer examination 
Coisas de nada, naturais da vida, insignificâncias do usual e do reles, poeira que sublinha com um traço fininho ${ }^{14}$ e grotesco a sordidez e a vileza da minha vida humana.

Todos nós, que sonhamos e pensamos, somos ajudantes de guarda-livros num armazém de fazendas, ou de outra qualquer fazenda, em uma Baixa qualquer. Escrituramos e perdemos; somamos e passamos; fechamos o balanço e o saldo invisível é sempre contra nós.

Todos têm um chefe de escritório com a piada sempre inoportuna e a alma fora do universo em seu conjunto. Todos têm o patrão e as amigas do patrão, e a chamada ao telefone no momento sempre impróprio em que a tarde admirável desce e as amantes inventam desculpas ou antes arriscam falar contra o amigo que está tomando o chá chic como os outros sabemos.

Mas todos os que sonham, ainda que não sonhem em escritórios da Baixa, nem diante de uma escrita de armazém de fazendas, todos têm um Caixa diante de si - seja a mulher com quem casaram, seja a administração dum futuro que lhe vem por herança, seja o que for logo que positivamente seja -, o Caixa aberto diante de olhos cuja vida sonha com todos os orientes; a piada inofensiva do chefe do escritório que ofende todo o universo; $o$ avisar o patrão que telefone, que é a amiga, por nome e dona, no meio da meditação do período mais insexual de uma teoria estética e inútil.

Depois os amigos, bons rapazes, bons rapazes, tão agradável estar falando com eles, almoçar com eles, jantar com eles, e tudo, não sei como, tão sórdido, tão reles, tão pequeno, sempre no armazém de fazendas ainda que na rua, sempre diante do livro caixa ainda que no estrangeiro, sempre com o patrão ainda que no infinito.

Escrevo sorrindo com as palavras, mas o meu coração está como se se pudesse quebrar ${ }^{15}$, quebrar como as coisas ${ }^{16}$ que se quebram, em fragmentos, em cacos, em lixo, que o caixote leva num gesto de por cima dos ombros para o carro eterno de todas as Câmaras Municipais.
Ah, e de novo, como o protesto

1 a 2 fria 3 de /som/ 4 măos 5 tardo 6 rua 7 atacava 8 eu só 9 vago calor 10 sangue lento 11 como uma cheja 12 lugar 13 insuficiente 14 o coração 15 esquecimentos 16 para a vida 17 se matasse enfim 18 janelas de par em par 19 estendo-o à janela 20 como a uma can-

ga imensa 17 se

O primeiro e o segundo excertos, separados pela catalogação, foram sucessivamente escritos. O terceiro excerto, dactiloscrito, cuja conexão o indículo «(Chuva) estabelece, foi registado no verso de um dos manifestos. Aviso por Causa da Moral. Já manuscrita, e com as mesmas tipologia gráfica e tinta dos dois excertos de abertura, é feita a evocação do bom abandono duma sesta tropical. $\mathrm{O}$ último excerto é dactilografado pela mesma máquina do anterior, com o último parágafo muito rasurado e corrigido a tinta preta.

$\mathrm{O}$ texto reune os trechos dispersos pela catalogação, recuperando o documento original, a percepção de como ele foi composto e os respectivos gestos de escrita.

Quando outra virtude não haja em mim

1 homem modesto 2 pelos prazeres alegres e tristes

[A REALIDADE ANAFRODISIACA]

A REALIDADE ANAFR

A persistencia instintiva da vida

A maioria, senão a totalidade dos homens, vive

A maioria dos homens vive com espontaneidade

Coisas de nada, naturais da vida

1 dores, salvo naquelas que se fundamentam na morte, porque nelas colabora o Mistério porque para elas contribui o Mistério (e a mesma vida se desmente) 2 desatençăo 3 sobem/fluidos $/ 4$ como 5 interfluentes 6 riscar redondo 7 movimento 8 silêncios 9 (meio-fado) 10 da 11 longos $12 \mathrm{mesma} /$ sensaçăo/consciência $13 \mathrm{e}$ tocam a / trintina a 14 apagado / tremididnho 15 partir 16 partir como as coisas

O título atribuído a esta sequência figura no projecto editorial reproduzido a seuir e, como expressão, ocorre no segundo excerto cujo apontamento inicial( autor depois integrou no desenvolvimento do texto.

trecho "Coisas de nada, naturais da vidas é antecedido pelo breve projecto para Álvaro de Campos:

\section{Ode à Realidade das Coisas}

A Realidade Anafrodisfaca

Aconteça o que acontecer, aconteceu quando acontecer.

Em duas pequenas folhas, já dobradas de origem, o registo é feito ao acaso, devaneando a partir dos vincos, enviesando o espaço disponível e cruzando-o. Parece, contudo, recuperada a ordem discursiva original.

A VIAGEM NA CABEÇA

Do meu quarto ardar sobre o infinito

Apontamento de tipo encantatório, registado no mesmo suporte do trecho anterior, aparentemente fazendo projecção para o texto «Marcha Fúnebre para o Rei Luís Segundo da Baviera". Sempre me tem preocupado 1 ausência de comunicaçăo

Figure 2. Transcription and critical apparatus in Cunha for manuscript E3, 1-71-71a. Information about variants and other textual and material features is provided in endnotes (Pessoa 2008, 311, 646).

also reveals that she has intervened in redefining textual units: her edition contains far more divisions and rearrangements than any of the others, and she often creates additional paragraph divisions to produce what she feels as stronger semantic or narrative coherence. Her textual invasions are clearly meant to minimize the compositional fragmentariness of the work, in the hope that graphical juxtaposition of texts reinforced by semantic or stylistic affinities will coalesce into some kind of organic whole.

Zenith's edition, similarly to Coelho and Cunha, declares upfront that the selection and ordering of textual pieces are rooted in his literary interpretation of the original witnesses. In this case, Zenith organizes fragments in an assumed subjective manner taking as the works' major axis those texts that are attributed to Bernardo Soares, which provide a framework around which he intersperses fragments written much earlier. He hopes that the framework formed by the later pieces will contaminate its themes and tones to the earlier pieces. The editor notes: 
It is impossible to present fairly the text of the Book of Disquiet, marked by hundreds of variants - words or phrases left by the author in the margins and between the lines as amendment proposals, usable for final revision that, in most cases, he did not make. Some variants hardly "vary", being exact synonyms, or merely changes in the use of prepositions or articles, while others are more of a stylistic kind. There are others still that can profoundly transform the meaning of a sentence, but these cases are rare. That we choose, or not, an alternative form present in the original has generally far less significant effects in the case of the Book of Disquiet than in Pessoa's poetry. Anyway, all variants are recorded at the end of the volume, together with other relevant information. Endnotes also indicate, by means of an asterisk, those c. 50 pieces of text ["trechos"] that are hypothetically included in the book, lacking an explicit attribution of the author and not showing content (the presence of Bernardo Soares or of the world of the Rua dos Douradores [Street of the Gilders]) that would make such an assignment inevitable. (Zenith in Pessoa 2012, 35; our translation)

"It is impossible to present fairly the text of the Book of Disquiet", writes Zenith. The interesting thing about this sentence, beyond highlighting the work's variable fragmentary basis, is the phrase "the text of the Book of Disquiet". In the same way that Pessoa works with the idea of the book as a potential horizon for his writing gestures, a horizon that he never quite reaches, the editors have to conceive of a book and close between cover boards that which Pessoa never finished. In any case, the "text of the Book of Disquiet" is an interpretation of the editor, in this case Zenith, based on that variable and uncertain basis. One is required to distinguish between "text" understood as the corpus of selected fragments, and "text" as the content of each fragment, i.e., letters that form words that form sentences that form paragraphs. In either case, textual representation requires interpretation by the editor, both to select those fragments that constitute the corpus of the Book of Disquiet, and for interpreting Pessoa's actual written marks, some of which are almost illegible and have originated entirely different conjectural readings. ${ }^{3}$

3. Although a few conjectural readings still persist, many once illegible passages have been deciphered over the years. Once a likely reading is offered by someone it is soon (and silently) adopted by all editors. Although editions retain their structural differences in selection and organization, their textual transcriptions (with the exception of Coelho 1982, which has only reprinted once without 
419.

Coisas de nada, naturais da vida, insignificâncias do usual e do reles, poeira que sublinha com um traço apagado ${ }^{1}$ e grotesco a sordidez e a vileza da minha vida humana - o Caixa aberto diante de olhos cuja vida sonha com todos os orientes; a piada inofensiva do chefe do escritório que ofende todo o universo; o avisar o paträo que telefone, que é a amiga, por nome e dona, no meio da meditaçáo do período mais insexual de uma teoria estética e inútil.

Depois os amigos, bons rapazes, bons rapazes, tâo agradável estar falando com eles, almoçar com eles, jantar com eles, e tudo, náo sei como, táo sórdido, tão reles, táo pequeno, sempre no armazém de fazendas ainda que na rua, sempre diante do livro caixa ainda que no estrangeiro, sempre com o patráo ainda que no infinito.

Todos têm um chefe de escritório, com a piada sempre inoportuna, e a alma fora do universo em seu conjunto. Todos têm o patrāo e a amiga do patrāo, e a chamada ao telefone no momento sempre impróprio em que a tarde admirável desce e as amantes inventam[?] desculpas ou antes avisam pelos outros da amiga - que está tomando o chá chic como os outros sabemos.

Mas todos os que sonham, ainda que não sonhem em escritórios da Baixa, nem diante de uma escrita de armazém de fazendas - todos têm um Caixa diante de si - seja a mulher com quem casaram, seja a administração da fortuna que lhes vem por herança, seja o que for, logo que positivamente seja.

Todos nós, que sonhamos e pensamos, somos ajudantes de guarda-livros dum Armazém de fazendas, ou de outra qualquer fazenda, em uma Baixa qualquer. Escrituramos e perdemos; somamos e passamos; fechamos o balanço e o saldo invisível é sempre contra nós.

Escrevo sorrindo com as palavras, mas o meu coraçáo está como se se pudesse partir, partir ${ }^{2}$ como as coisas que se quebram, em fragmentos, em cacos, em lixo, que o caixote leva num gesto de por cima dos ombros para o carro eterno de todas as Câmaras Municipais.

E tudo espera, aberto e decorado, o Rei que virá, e já chega, que a poeira do cortejo é uma nova névoa no oriente lento, e as lanças luzem já na distância com uma madrugada sua.
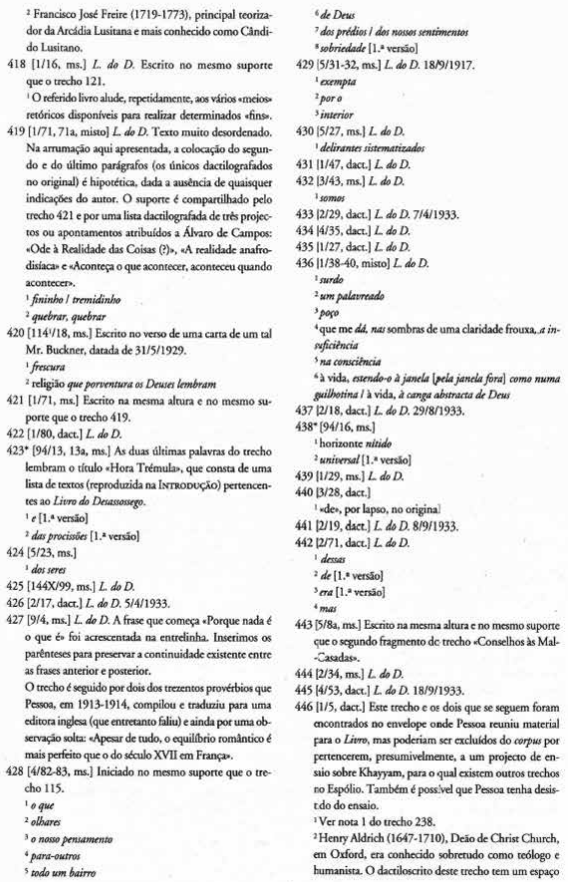

Figure 3. Transcription and critical apparatus in Zenith for manuscript E3, 1-71-71a. Information about variants and other textual and material is provided in endnotes (Pessoa 2012, 379, 529).

Besides making much of the same claims as previous editors, Pizarro's critical and genetic edition includes a second volume with an extensive critical apparatus that accounts for the genetic process of creating the work, carefully signaling in each fragment divergences with other editions, as well as his own interpretation. With Pizarro's edition the discussion on how to edit Pessoa's papers adopts an editorial rationale that had not been taken before. Pizarro edits the book trying to represent the genetic writing process and he sequences the selected corpus in chronological order. The guiding criterion for his bibliographic intervention is to date all fragments on the basis of textual or material evidence, and follow the sequence in

changes in 1997) are almost identical - the major difference being the modernization of orthography in Cunha 2008 and Zenith 2012, and the use of Pessoa's orthography in Coelho 1982 and Pizarro 2010. 
which the fragments were written. That decision also has consequences for the concept of authorship, when we consider the multiple heteronyms that Pessoa used for signing his writings. The chronological order clearly shows two different literary styles associated with two different names - Vicente Guedes and Bernardo Soares - corresponding to the two major periods of composition.

The organization of the present volume - the 12th volume of the Critical Edition of Fernando Pessoa - attempts to be as chronological and objective as possible. I have sketched the principles governing this organization - which does not differ from the model followed in other editions by the Pessoa Team - in volume IX, The Education of the Stoic, which I have always seen as a small scale Book. Both works are partially coincident in time, and Barão de Teive and Bernardo Soares are considered by Pessoa as semi-heteronyms or alien figures of me [figuras minhamente alheias] (16-58r; see "Appendices"). This edition also seeks a "strong compromise between materiality and meaning"; and its organization also "does not respond to a subjective reading of the contents of individual parts, but to a careful study of each of its supports". (Pizarro in Pessoa 2010, 9)

Despite the technical quality of Pizarro's material and documentary analysis of the writing process, the crucial issue has to remain open: how can we articulate the semantic interdependence between the fragment and the Book as an edited whole? In the end this interdependence is always produced by the editor who interprets the writings as textual fragments and the textual fragments as bibliographic sequence. Each Book of Disquiet - as both the transcription of texts written by Pessoa and the ordering of a selected set of texts - is the result of an editorial interpretation of a discursive network of semantic relations and a documentary network of inscribed papers.

\section{The kinetics of scripting}

Textual units of the Book of Disquiet - generally referred to as "fragments" - fall into three groups: twelve published texts ${ }^{4}$, which are several

4. Texts ["Trechos"] from the Book of Disquiet were published in the following periodicals: A Águia, nº 20 (August 1913, pp. 38-42), A Revista No 1 (1932, p. 8), A Revista $\mathrm{N}^{\circ} 2$ (1929, p. 25), A Revista $\mathrm{N}^{\circ} 4$ (1929, p. 42), Presença $\mathrm{N}^{\circ} 27$ (June- 
Texto Crítico

$185 \quad\left[\mathrm{I}-7 \mathrm{Ia}^{\mathrm{T}}\right]$

[1929?]

Depois os amigos, bons rapazes, bons rapazes, tão agradavel estar fallando com elles, almoçar com elles, jantar com elles, e tudo, não sei como, tam sordido, tam reles, tam pequeno, sempre no armazém de fazendas ainda que na rua, sempre deante do livro caixa ainda que no estrangeiro, sempre $\mathrm{com}^{\mathrm{t}} \mathrm{o}$ patrāo ainda que no infinito.

E tudo espera, aberto e decorado, o Rei que virá, e já chega, que a poeira do cortejo é uma nova nevoa no ${ }^{2}$ oriente lento, e as lanças luzem já na distancia com uma madrugada sua.

$$
186\left[\mathrm{I}-7 \mathrm{I}^{\mathrm{v}} \text { e } 7 \mathrm{Ia}^{\mathrm{v}}\right] \quad \text { [1929?] }
$$

L. do D.

Coisas de nada, naturaes da vida, insignificancias do usual e do relest, poeira que sublinha com um traço tremidinho ${ }^{2}$ e grotesco a sordidez e a vileza da minha vida humana.

- O Caixa aberto deante dos olhos cuja vida sonha com todos os orientes; a piada inofensiva do chefe do escriptorio que offende todo o universo; o avisar o patrăo que telephone, que é a amiga, por nome e dona, no meio ${ }^{3} \mathrm{da}$ meditação do periodo mais insexual de uma theoria esthetica e inutil. ${ }^{\text {s }}$

Mas todos os que sonham, ainda que não sonhem em escriptorios da Baixa, nem deante de uma escripta do armazem de fazendas - todos teem um Caixa deante de si - seja a mulher com quem casaram, seja a administração da fortuna que lhes vem ${ }^{6}$ por herança, seja o que fôr, logo que positivamente seja.?

Todos teem um chefe de escriptorio, com a piada sempre inopportuna, e a alma fóra do universo em seu conjunto. Todos teem o patrâo, e a amiga do patrão, e a chamada ao telephone no momento sempre improprio em que a tarde admiravel desce $\mathrm{e}$ as amantes antes descobertas como amantes ${ }^{8}$ avisam pela linha ${ }^{9}$ da amiga que está tomando o chá chic como as outras senhoras. ${ }^{10}$
Aparato: textos $184-186$

anaphrodisiaca que não entra na minha imaginaçăo $\left(5-68^{*}\right) ; T$. S. Cunha decidiu dar esse titulo a uma sequência de quatro textos em Livro do Desassossego (2008: 626).

Aparato Genético

I $\langle$ sob $\rangle /$ com $\backslash]$ correç̧ã $\tilde{a}$ manuscrita a lápis.

na ] no original.

Anexo $\left[\mathrm{I}-7 \mathrm{ra} \mathrm{a}^{\mathrm{N}}-\right.$ dact. $]$

Aluaro de Campos.

Ode á Realidade das Coisas. (?)

A realidade anaphrodisiaca

Aconteça o que acontecer, aconteceu quando acontecer.

$186\left[\mathrm{I}^{-7 \mathrm{I}^{\mathrm{v}}}\right.$ e $\left.7 \mathrm{I}^{\mathrm{v}} \mathrm{v}\right]$

Materiais: ver a descrição do texto que comeģa Depois os amigos $\left(1-7 a^{*}\right)$. Este escrito, manuscrito a lápis, foi publicado, conjuntamente com outros fragmentos, em Livro do Desassossego ( $5982: I, 120-130$; ver o fac-simile entre as paginas 70 e $7 \pi$. Do parágrafo que comega Todos teem um chefe de escriptorio existe

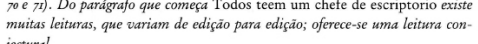
jectural.

Aparato Genético

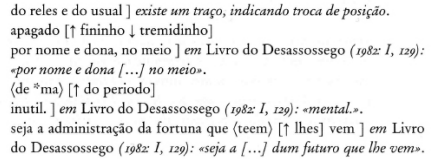

Figure 4. Transcription and critical apparatus in Pizarro for manuscript E3, 1-71-71a. Exhaustive information about variants and other textual and material is provided in a separate volume (PessoA 2010, 187, 757).

pages long, dating to the first phase of writing, often described as "symbolist"; a few hundred typescripts, most of which fit into a single page - many of these contain handwritten emendations, a few contain additional handwritten paragraphs; a few hundred manuscripts, most of which constituted by a few paragraphs, sometimes containing emendations. Many of these texts are marked "L. do D." by Pessoa, an indication that they were meant for Livro do Desassossego, and some of them are also dated. They are generally type- or handwritten on loose sheets but a small number of fragments is included in notebooks containing other writing projects. Textual and discursive divisions often coincide with the surface of inscription (for instance, most typewritten fragments fit within one page), but there also instances where paragraph spacing, horizontal rulers and other

July, 1930, p. 9), Descobrimento no 3 (1931, pp. 405-415; 5 texts), Presença $\mathrm{N}^{\circ} 34$ (1931-1932, p. 8), and Revolução No 74 (June 7, 1932, p. 3). 


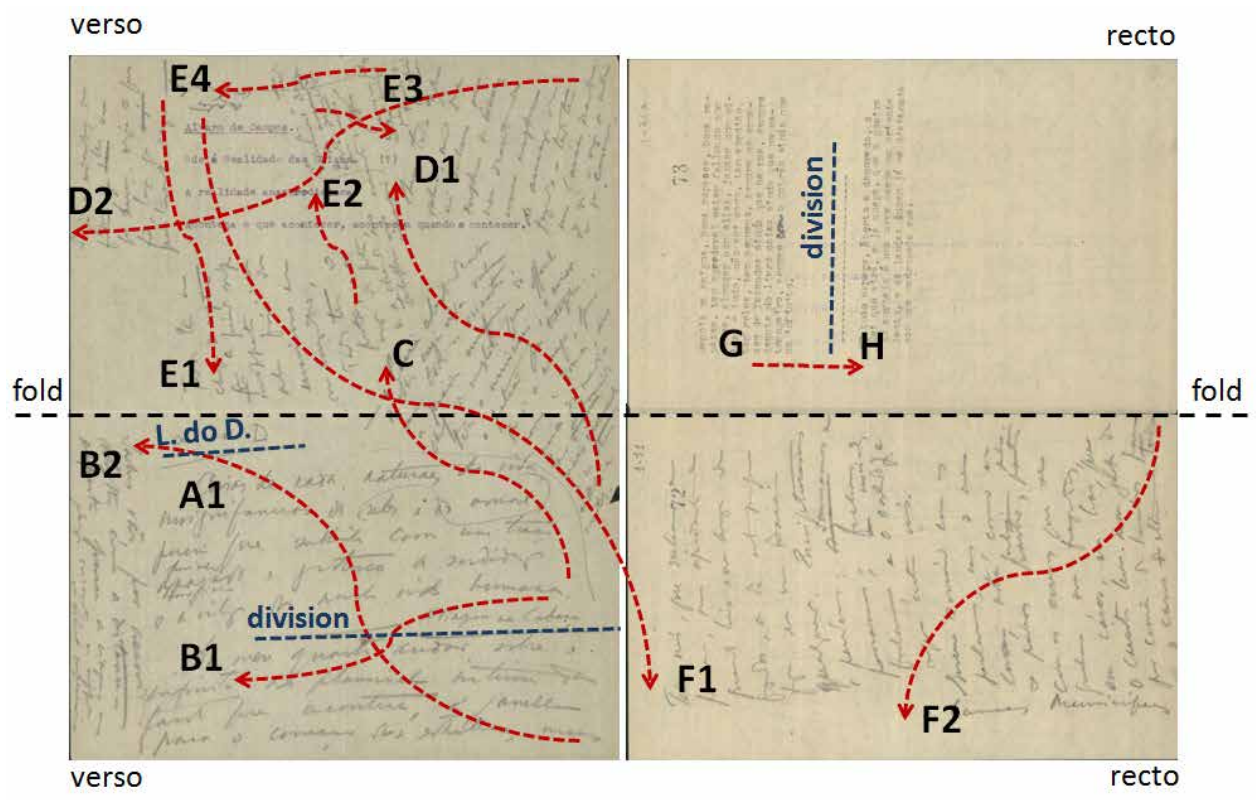

Figure 5. Writing in fragments: the centrifugal and contrapuntal dynamics of selfconsciousness in E3, 1-71-71a. CNational Library of Portugal [digital facsimile references: bn-acpc-e-e3-1-1-89_0144_71v_t24-C-R0150 / bn-acpc-e-e3-1-1-89_0143_71 _t24-C-R0150 / bn-acpc-e-e3-1-1-89_0145_71a_t24-C-R0150]. Reproduced with permission.

meta-marks - particularly in handwritten texts — can be used for marking semantic units. If we exclude the limited number of early large pieces that are several pages long, the average size of textual units marked for inclusion in the Book of Disquiet is only a few paragraphs long. This size suggests that Pessoa's autograph units of writing in the Book of Disquiet generally correspond to temporal units of writing.

In this section we analyze Pessoa's writing process by examining one example (E3, 1-71-71a) where the dynamics of filling in the page helps us to understand the material and temporal kinetics of writing as evidence of his fragmentary method. Rather than being merely a contingent result of external circumstances, the textual fragment seems to have been the product of the temporality of the scripting act as a cognitive exploration of writing-thinking feedbacks. Each textual piece can be read as an embodied neurological unit of focused attention in the exploration of self-consciousness. 
The autograph documents reproduced in Figure 5 [BNP-E3-1-71v and 71a-v (left-hand side, bottom and top)-71 (right-hand side, bottom)-71a (right-hand side, top)] reveal material and textual features that we find in other pieces of the Book of Disquiet. This folded sheet of paper contains both typescript and handwritten text, indicating at least two different moments of composition. Both the typescript and handwritten areas contain graphical marks of textual division: in the typescript area, a dashed horizontal ruler indicates that the second typed paragraph is a different semantic unit; in the manuscript area, we find the mark "L. do D." that identifies this text as a piece of writing meant for the Book of Disquiet, and also a handwritten horizontal ruler preceded by a title, again indicating that this part forms a particular semantic unit that can be distinguished from the paragraphs in the surrounding areas.

This example shows how variations in textual units in each edition depend on the way editors interpret the relation between textual and material contiguity: the co-presence of textual units on the same inscription surface can be used as a criterion for transcribing those units as part of the same fragment. Material contiguity is used for constructing textual unity. We may say that the fragment understood as a discursive unit of composition - indicated in many autograph manuscripts by marks of division between paragraphs or groups of paragraphs — overlaps the fragment understood as a piece of written paper. This document contains at least four internal sections (two typescript sections and two manuscript sections), but it has been edited either as one fragment (edition by Jacinto do Prado Coelho, text $\mathrm{n}^{\circ} 124$ - Figure 1 above), two (editions by Teresa Sobral Cunha, pp. 311-312, and Richard Zenith, texts n 419 and 421 Figures 2 and 3 above), or three (Jerónimo Pizarro, texts $\mathrm{n}^{\circ}$ 185, 186 and 187 - Figure 4 above). Editions also vary in the internal organization of paragraphs: Jacinto do Prado Coelho and Teresa Sobral Cunha place one of the typewritten paragraphs interpolated as the fifth paragraph within the handwritten text; Richard Zenith places it as the second paragraph; while Jerónimo Pizarro treats both typewritten paragraphs as an autonomous unit that follows the handwritten text. Editors organize material and textual evidence according to perceived discursive form.

The kinetics of writing on the surface of manuscript BNP-E3-1-71-v and $71 \mathrm{a}-\mathrm{v}$ suggests that this paper sheet was rotated in clockwise and counterclockwise directions five times (Figure 6a). The pattern of distribution on the page suggests that the temporal sequence of inscription was as indicated in A-E4 (Figure 6b). Script areas A, C, D1, D2, E1, E2, E3 and E4 seem to belong to the same semantic unit. Areas B1 and B2 seem to form 
Figure 6a.

Filling in the page: the kinetics of writing for E3-1-71v. (C)National Library of Portugal [digital facsimile reference: bn-acpc-e-e3-1-189_0144_71v_t24C-R0150]. Reproduced with permission.

Figure 6b.

The kinetics of writing and the inner logic of fragments.
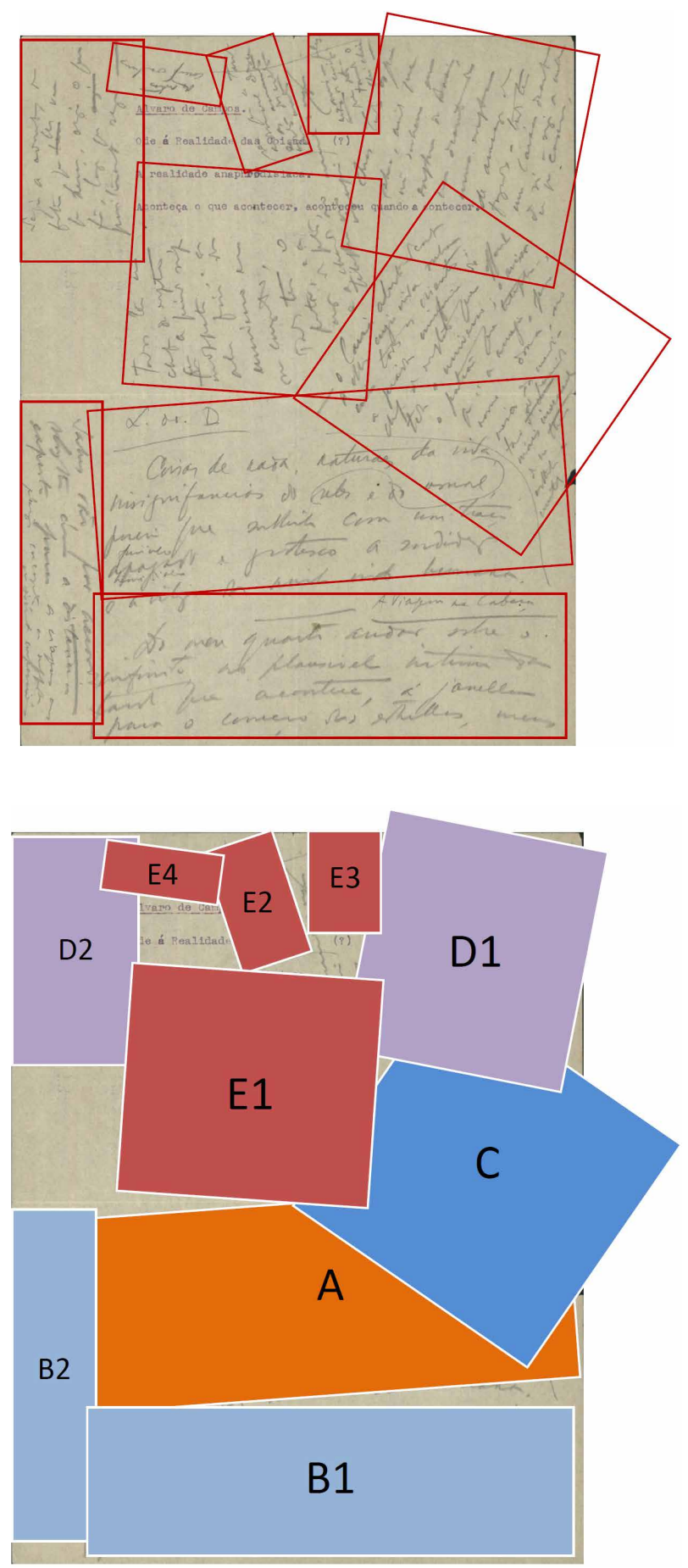
a different semantic unit. This autograph manuscript shows the process of accretion and internal differentiation of the fragment as both a kinetic register of a script act and a semantic textual unit developing towards a textual whole. In the case of the Book of Disquiet this whole is both the selfconscious unity of the fragment, and the perceived potentiality of writing for generating stylistic and thematic coherence at larger scales. Although each piece of text desires to place itself in the larger imagined structure of the book, each piece of text is also a self-conscious self-contained unit. This fragmentary logic thus becomes a built-in feature of Pessoa's writing process.

Analysis of textual inscription on this particular page suggests the following scripting dynamics:

a) The temporal sequence of inscription on the different areas of the paper seems to be A, B, C, D and E (this choreographic motion was also determined by the fact that this sheet was folded in half).

b) Text in area B ("A Viagem na Cabeça" ["Journey in the Mind"]) is marked by a horizontal line of division that suggests the beginning of another fragment. Its semantic markers are also different from those of text in area A. The title "Journey in the Mind" may belong to a later script act, since the pencil does not have the same thickness of the entries in either area A or B. Graphic markers (line of division, title) and content features (semantic unity) reinforce the process of textual differentiation.

c) After writing the text in area B, Pessoa would have reread the text in area $\mathrm{A}$, which contrasts semantically with the text in area B. In this case, Bernardo Soares is presented as a dreamer in his room, in the other, Bernardo Soares is shown as a bookkeeper in the warehouse - "the sordidness and vileness of my human existence". Rereading area A may have suggested the list of topics that expand on the idea stated in the text in area A through observations about the daily business of the office.

d) Thus temporal inscription of the page areas is A, B, C, D, and E, but semantic consistency suggests that it may be divided into two different fragments or pieces: one with the text areas A, C, D, E (+ F, on the recto face, shown above in Figure 5), the second text constituted only by area B (Fragment "A Journey in the Mind"). The act of assigning a title to the second fragment suggests that this paragraph could eventually be integrated or subsumed in some other text containing 
this topic, or that this fragment could be in itself the beginning of a possible fragment on mental journeys of Bernardo Soares.

Through a detailed analysis of these pages it is possible to highlight several aspects of temporality and reflexivity in the act of writing:

a) Occupation of the various areas contains a chronology of inscriptions for the script acts: how each piece of text is laid out around the contours of others shows us the relative chronology of inscription of each piece of text.

b) Writing explores the potentiality opened up by feedbacks between thought and inscription and often unfolds without a prior plan for occupying the paper: the text is not inscribed according to a linear distribution (filling in the leaf from top to bottom always in the same direction) because its development stems from the process itself. An initial area selected as a scripting field may prove insufficient, and it may trigger another circular or perpendicular movement to occupy another area of the page. The hand moves across the inscriptional surface in several directions. In this case five different paper rotations shifted the handwriting in both clockwise and counterclockwise directions. The size of the handwritten letters gets smaller as one tries to fit additional sentences into the decreasing available space.

c) The process of constructing semantic unity through the addition of sentences and paragraphs works either by contrast - a particular semantic unit can generate, by contrast, a new semantic unit (relationship between A and B) — or by similarity, i.e., by adding or subsuming topics (relationships between A, C, D, E and F). Fragments thus take their self-conscious shape through processes of internal repetition and differentiation.

d) Rereading can strengthen the unity of a script act by assigning a title that gives further conceptual unity to a fragment, or by redistributing paragraphs according to later revision acts.

This analysis of the temporal and semantic dynamics of writing enables us to consider the notion of fragment at several levels:

a) The fragment as a piece of paper. In this case the incompleteness of the inscription is the consequence of the incompleteness of its inscriptional surface - for example, a missing or misplaced leaf, i.e, either lost or placed outside the temporal and semantic order of inscription. 
This type of fragmentation is contingent on partial degradation or partial loss of a document.

b) The fragment as a piece of writing. The incompleteness of inscription results from the incipient nature of the text - as in text $B$, for example - suggesting the possibility of continuation, revision and rewriting. Loose sentences or phrases may be annotations for further expansions. This type of fragmentation is contingent on the drafting process.

c) The fragment as a piece of writing susceptible of belonging to a larger unit, with more or less strong semantic unity. Such fragments could then be sequenced with other fragments of the same type. In this latter instance the text may be finished as a textual unit (as is the case with many pieces of the Book of Disquiet, as happens with the large pieces published in 1913 and, more generally, with typescripts), but its relative position within the book as whole has not been determined. Its fragmentary condition results from this divergence between its closed internal form and its open and undetermined place within a final imagined longer text.

d) The fragment as a genre in itself, that is, a piece of text that asserts its fragmentariness as a stylistic and structural feature. Although these textual pieces may form a larger whole, they are self-conscious about their fragmentary unity.

Fragments of type $\mathrm{c}$ and $\mathrm{d}$ can be said to have been the unit of composition of the Book of Disquiet, in its authorial form, while fragments of type $a, b$ and $\mathrm{c}$ are the unit of composition in the work's posthumous editorial forms. We could say that the accretion process required for the autograph production of the Book of Disquiet results from the ordering and revising/rewriting of pieces of text that have a certain semantic unity but which are also self-consciously fragmentary in their finished forms. Dilemmas faced by the editors - reenacting dilemmas faced by the author in his notes and plans on how to organize the Book of Disquiet - result from this codetermination between parts and whole. The chosen fragments and the sequencing of those fragments is made with a certain conception of the whole (a certain idea about what the writing of the Book of Disquiet is or should be), but at the same time that perceived whole is the product of actual choices about the structure and form of its constituent parts.

In the case of the Book of Disquiet, there are varying degrees of semantic and discursive unity, which tend to be reflected in the stages of revision that we can infer from print, typescript and manuscript witnesses. 
Semantic and discursive unity is generally stronger in large printed texts ("Trechos") and typescript pieces, and weaker in short manuscript passages where there is no reiteration and expansion of a particular topic or where there are no signs of systematic revision acts. The semantic unity of textual fragments and their relative length is partly correlated with acts of revision and rewriting: it is generally stronger in typescripts than in first draft manuscripts, because these may be less self-reflexive and result from the temporality of the first act of inscription. Each sentence or phrase triggers a process of association with sets of sentences or phrases that follow at a given moment of continued and sustained writing focus. However, in the Book of Disquiet there are several texts where there seems to be no significant difference between manuscripts and typescripts, and several heavily corrected typescript texts may have been written directly on the typewriter without a prior handwritten draft. This kinetic temporality of handwritten or typewritten inscription produces in itself a semantic and material coherence that comes from its existence at a given moment in time.

In our view, the fragmentariness of the Book of Disquiet is also the result of the fragmentariness of the temporality of inscription. Each textual fragment produced as a sustained writing-thinking moment can maintain its fragmentary nature or it can also be subjected to an associative logic with fragments of text written at other moments. In this case, the association of two distinct script acts could converge in a larger semantic unity, giving rise to a more extended fragment. But acts of revision of this type do not seem to be very common, except in the small set of longer and often titled texts ["trechos"] that appear as the result of an elaborate process of rewriting and revision. What seems to be more frequent in the Book of Disquiet is the act of starting over again, as if each kinetic sequence of paragraphs were independent of previously written sets of paragraphs, even when they contain similar topics and concerns. This mechanism for starting a new reflection and sustaining it for several paragraphs suggests that each script act was experienced within the limits of the biological rhythms of concentrated attention. This process is consistent with Pessoa's writing method centered on a moment by moment description of the world through a verbal intensification of self-conscious sensations.

Pessoa/Bernardo Soares seems to have become used to writing as if every writing moment would initiate a new text. He writes a sentence and then deals with the consequences of that sentence until exhausting its implications or its images. This writing method captures the temporal kinetics of writing, that is, the fact that each act of continuous writing can only last for a certain amount of time (from several minutes to a few hours). The 
subsequent production of the projected book would involve revising and (re)ordering these kinetic units in a much longer temporal and discursive horizon. However, the greater the number and semantic dispersal of the fragments, the more difficult the rewriting and (re)ordering of fragments becomes. Although he kept writing with the conceptual and material horizon of the book in mind, the fragmentary kinetics of writing tends to dominate in his creative processes. Pessoa conceived books for his several heteronyms and he managed to finish many texts attributed to them, particularly those signed by the poets Alberto Caeiro, Álvaro de Campos, and Ricardo Reis. However, he was unable to come to final decisions about the exact contents of each of their planned books.

\section{Fragment, book, self}

Representation of stages and layers of writing and revision has been the basis of codex critical editions that represent textual construction by marking earlier or potential forms contained in the work's archive. In the case of the Book of Disquiet, the work's archive is itself partially undeterminable since its textual corpus fluctuates according to particular editorial decisions. Editors have to select elements from the author's archive, mark them as belonging to the Book of Disquiet on the basis of material and stylistic evidence, place these elements in a hypothetical bibliographic sequence, and produce the result as a textual whole. Each editorial selection is different, and the relative order chosen for placing the texts and fragments selected is also unique. From these editorial interventions different books of disquiet emerge. In fact, the editorial process of selecting and ordering pieces of text to produce a book is similar to an authorial intervention on the archive of the work. Pessoa would have to edit the writings of his semiheteronym Bernardo Soares in order for the Book of Disquiet to gain the psychological and stylistic unity that he imagines:

\section{L. do D. (Note)}

The organization of the book should be based on a choice, as rigid as possible, from the existing varying texts ["trechos"], adapting, however, the older ones, which may fail the psychology of Bernardo Soares, as it now appears, this true psychology. Apart from this, a general revision of his own style, without letting it lose, in its intimate expression, the reverie and disjointed logic that define him. (Pessoa 1982: 8; our translation) 
As we have seen above, writing takes place as process that explores the potential of the fragment as a function of the writing process itself. This may be described as a major difference between the Romantic and Modernist uses of fragment: in the first instance, as quoted or constructed pieces from external sources (imaginary or not), textual and material evidence of ruins that point beyond themselves, according to an aesthetics of genre; in the second instance, as a fragmentary totality that is complete and incomplete at the same time, and whose fragmentary nature is an internal textual property. The modernist aesthetics of the fragment as genre is predicated upon types of fragment that have been described in these terms by Camelia Elias: "the fragment is essentially different from the full text as it is able to both actualize a full text's completeness and survive that actuality in becoming a totality itself" (Elias 2004, 49).

As in other modernist works, we may say that in the Book of Disquiet the fragment is not a mere contingent or circumstantial piece whose incompleteness originates in its own unfinished state, although some of its fragmentary texts would also correspond to this description (cf. instances a and $\mathrm{b}$, above). Rather it is also a mode and genre of writing that produces the fragmentary as an attribute of its own internal constitution. In this case, the fragmentary nature of writing is not mere evidence of compositional hesitations and interruptions - stylistic experiments, paradoxical uses of language, repeated attempts at giving written form to thoughts, and thinking through writing - but the literary expression of the reflexive exploration of the potentiality of writing. The fragment, rather than the book or any stable and recognizable textual form, emerges as the very condition of textuality. Fragmentation functions as a framework for showing writing as a process of becoming that gives form to a certain state of mind. Pessoa/ Vicente Guedes is aware of this dynamics between potentiality and actuality when he self-consciously describes his writing process as an accumulation of fragments: "My state of mind compels me to work hard, against my will, on the Book of Disquiet, but it's all fragments, fragments, fragments" (From Pessoa's letter to Armando Cortes-Rodrigues, 19 November 1914; Pessoa 2002, 9, translation by Richard Zenith).

This reference to the experience of the fragment in writing is also an image of the discontinuous and hollow phenomenological experience of the self as constituted through language. Subjective existence cannot be captured or given form in writing except as a series of discontinuous fragments that have to be supplemented by an actual reading act, a material replication of the unity of self-consciousness as a neurological product of multiple pulses of brain activity. Pessoa's heteronyms can be described as 
a written dramatization of this self-differentiation process that reveals the self as a fragment to itself: "I, who dare write only passages, fragments, excerpts of the non-existent I myself — in the little that I write - am also imperfect" (Pessoa 2012, Text 85)..$^{5}$ Self-describing the Book of Disquiet as "Fragments of an Autobiography" (Pessoa 2002, 251), Pessoa turns the fragmentary nature of writing into a mirror image of the fragmentary nature of the self. The potentiality of being and the potentiality of writing coalesce in the fragment.

We claim that Pessoa's textual pieces for the Book of Disquiet should be understood as fragments in those two distinct but related senses: as expressions of the modernist genre of the fragment as both a form of writing the act of writing and a form of writing the consciousness of the self, on one hand; and also as a series of written fragments of a larger text whose imagined wholeness remains in the process of being constructed. This latter tension between fragments (in various stages of completion or revision) and the projected whole (in its varied plans and versions) is essential for thinking about the dynamics of writing the self in relation to the structure and form of the book. As an artifact, the book establishes a totalizing horizon, one in which it is the very structure of the codex that is able to produce order and generate a sense of whole. And yet, Pessoa's sensationist process of writing - with its accumulation of sensations and fictional multiplication of perspectives and consciousnesses perceiving the world — generates enhanced sensations and perceptions of reality through a collection of fragments whose stylistic, narrative, and psychological coherence comes from this introspective and phenomenological experience of self-consciousness itself as a fragmentary process.

Dirk Van Hulle has recently argued for the value of digital collation of modern manuscripts not as a preliminary step for scholarly editing but as a tool for manuscript research (VAN Hulle 2013, 30-35). According to his perspective, digital editing can be used for studying multiple drafting as part of the cognitive process through which the act of writing and rewriting

5. The fragment as a mode of understanding both world and self is a cultural trope that has gained currency since the Romantic period. Friedrich Schlegel remarks, for example, that "the fragment is the real form of universal philosophy" (quoted in Elias: 112) or that "I can give no other 'echantillon' of my entire ego than such a system of fragments because I myself am such a thing" (quoted in Elias: 112). For an image of writing as a fragment of the self, see for instance Ralph Waldo Emerson: "I am a fragment, and this is a fragment of me" (quoted in Elias: 112). 
probes the workings of the extended mind through material interactions. If this cognitive approach to genetic criticism were applied to fragments of the Book of Disquiet, Pessoa's manuscripts and typescripts in their various layers of revision and emendation could also be analyzed as part of the construction of the mind of his heteronyms. The process of semantic and thematic accretion and variation found across several texts could be examined at smaller inscriptional scales of phrase and word. Textual transcriptions mapped onto autograph markings would offer us an image of this retroactive process of invention through inscription. In effect, a layered transcription of the material writing process would provide us with another probe into Pessoa's production of the written/speaking self, offering us a view into the kinetic and cognitive procedurality of writing-in-the-making and of the book-in-the-making.

\section{The fragmentary kinetics of the digital archive}

A clear reading text in any given editorial version would be only one way of experiencing the Book of Disquiet. Each fragment of any particular edition could be further reframed by being placed in the context of the work's authorial and of other editorial textual witnesses. This understanding of the work as an expression of the fragmentary kinetics of writing - which manifests itself as internal formal feature and external textual condition-makes it particularly suitable for an open exploration of the processability and modularity of the digital medium. Within the LdoD Digital Archive - a collaborative archive where readers will be able to see facsimiles and topographic transcriptions of the authorial documents, compare edited versions of the book, create their own virtual editions of the Book of Disquiet, and even rewrite fragments of their own - such textual encounter takes place in a network of editorial versions and authorial drafts that simulates the very dynamics of textuality (Portela and Silva 2014).

The tension between part and whole, inherent in the fragmentary kinetics of writing, implies that the form of the book works as a conceptual space of articulation that we cannot materially totalize just by selecting and ordering its writings. Contaminated by writing's and self's potentiality of becoming, it is as if the book, like the self, had become a fragmentary collection of fragments. Coincidence between discursive unity and material unity can only happen partially and provisionally. Our digital archive uses both concepts of fragment in the Book of Disquiet as the basis for electronic textual encoding, database structure, data model and interactive function- 


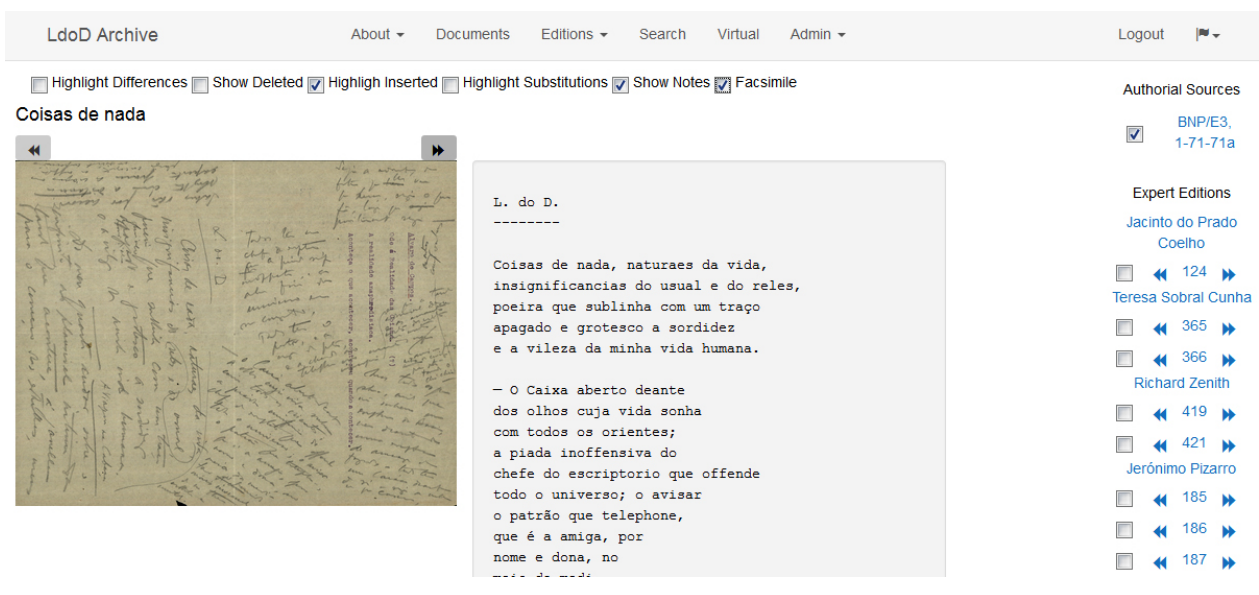

Figure 7. Screencapture of the $L d o D$ Archive prototype: digital facsimile vs. transcription of authorial source (E3-1-71-71a).

alities, in the hope that our digital remediation can result in a meta-representation of the fragmentary kinetics of writing and its potentiality for generating meaning. The encoding of those four critical editions, side by side with encoding of autograph materials, further explores the performative flexibility of the digital medium for an understanding of writing and reading acts in the production of textual form and bibliographic structure.

The fragmentary kinetics of the $L d o D$ Archive has been designed as a simulation of the textual and bibliographic dynamics of authoring and editing: genetic transcriptions can be seen in the context of editorial transcriptions, and vice versa; fragments can be seen in the context of books, and vice versa (Portela and Silva 2015). As can be seen in Figure 7, the right-hand side menu offers the possibility of combining vertical navigation in a particular edition (i.e., within a particular arrangement of the fragments according to a given book structure) with horizontal navigation throughout the entire archive (i.e., within the modular structure of textual pieces not yet organized according to any bibliographical principle). We can see, for instance, that authorial witness E3-1-71-71a corresponds to one fragment in Coelho, two in Cunha and Zenith, and three in Pizarro. We are also able to see their relative position within each of those four versions of the Book of Disquiet: 124 in Coelho; 365 and 366 in Cunha; 419 and 421 in Zenith; and 185, 186 and 187 in Pizarro. This radial structure creates the possibility of relating a genetic view of the process of writing to a social view of the process of editing. Because they will be able to select, 


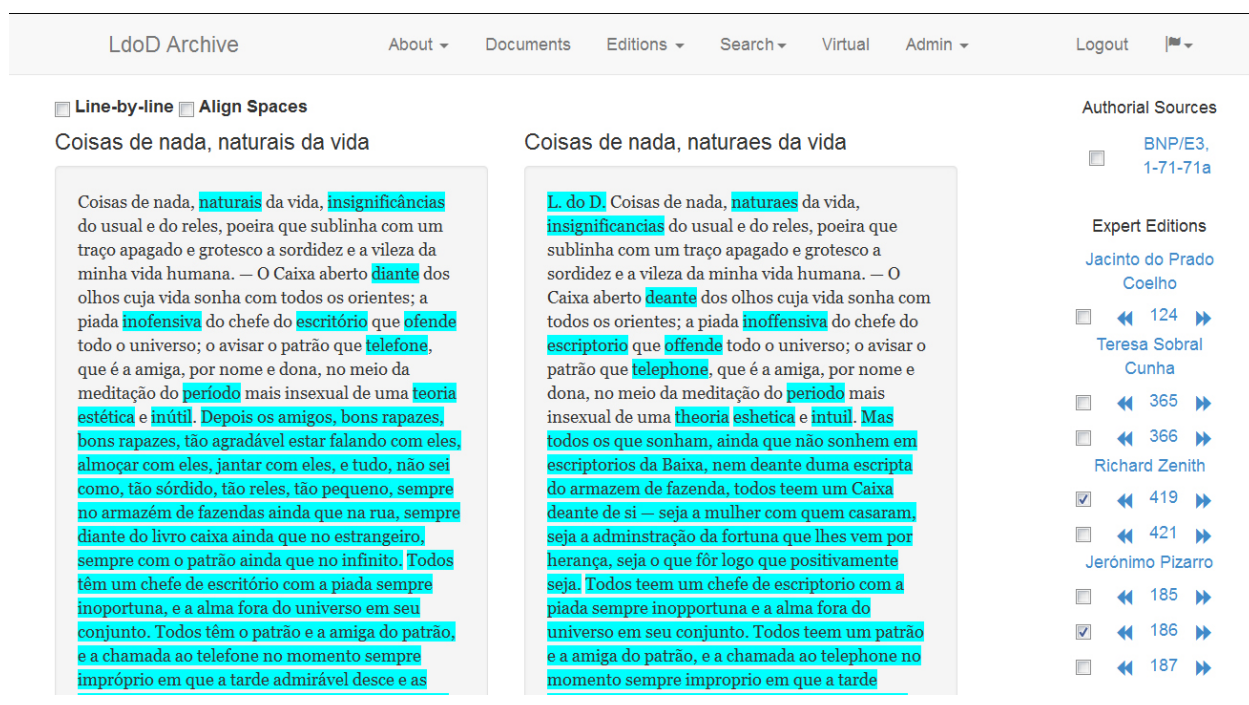

Figure 8. Screencapture of the $L d o D$ Archive prototype: side by side comparison between two editions of the same fragment (E3-1-71-71a according to ZENITH 2012 and Pizarro 2010).

annotate and structure the fragments, users can also perform an editorial role, and thus experience the back and forth movement between archive and edition, between written parts and projected whole.

The XML-TEI encoding of authorial and editorial variants and variations will enable users of the archive to see the kinetics of the scripting acts in relation to various editorial representations of those processes. Figures 8 and 9 show one-to-one and one-to-many textual comparisons between editions represented in the $L d o D$ Archive. Color highlights mark all points of variation across the various editions of this fragment, including smallscale variations - such as differences in orthography, but also authorial and editorial variants - and large-scale variations — such as differences in paragraph division and ordering. Figure 8 shows that Zenith and Pizarro have treated the internal textual divisions of this particular fragment differently. Figure 9 highlights variations at the scale of the paragraph and at the scale of words across the four critical editions. All editorial interventions - from orthographic normalization to readings of particular passages to internal rearrangement of paragraphs to the general division, selection and sequencing of texts - can be automatically visualized against each other but also against their respective authorial sources. 
L. do D. Coisas de nada, naturaes da vida, insignificancias do usual e do reles, poeira que sublinha com um traço apagado e grotesco a sordidez e a vileza da minha vida humana.

Coisas de nada, naturais da vida, insignificâncias do usual e do reles, poeira que sublinha com um traço apagado e grotesco a sordidez e a vileza da minha vida humana.

Coisas de nada, naturais da vida, insignificâncias do usual e do reles, poeira que sublinha com um traço apagado e grotesco a sordidez e a vileza da minha vida humana.

L. do D. Coisas de nada, naturaes da vida, insignificancias do usual e do reles, poeira que sublinha com um traço apagado e grotesco a sordidez e a vileza da minha vida humana.

- O Caixa aberto deante dos olhos cuja vida sonha com todos os orientes; a piada inoffensiva do chefe do

escriptorio que offende todo o universo; o avisar o patrão que telephone, que é a amiga, por nome e dona, no meio da meditação do periodo mais insexual de uma theoria eshetica e mental.

- O Caixa aberto diante dos olhos cuja vida sonha com todos os orientes; a piada inofensiva do chefe do

escritório que ofende todo o universo; o avisar o patrão que telefone, que é a amiga, por nome e dona, no meio da meditação do período mais insexual de uma teoria estética e inútil.

- O Caixa aberto deante dos olhos cuja vida sonha com todos os orientes; a piada inoffensiva do chefe do

escriptorio que offende todo o universo; o avisar o patrão que telephone, que é a amiga, por nome e dona, no

meio da meditação do periodo mais insexual de uma theoria eshetica e intuil.

Figure 9. Screencapture of the $L d o D$ Archive prototype: line by line comparison across four editions of the same fragment (E3-1-71-71a according to Coelho 1982, Cunha 2008, Zenith 2012 and Pizarro 2010).

Every revision mark that Pessoa made on the text is a heightened moment of awareness of the writing process. How is the self made present in the fragmentary acts of writing and revising? What emerges in those layers of scripting acts? How is this writing process related to the process of creating writing selves? A systematic encoding of writing and revision acts can help us see the textual construction of the self through this fragmentary kinetics of writing. The detailed representation of editorial interventions on the autograph materials will enable us to analyze the different mediations that lead from an open set of textual fragments to an edited book. Editorial interpretation results in the construction of a work and a portrait of its author. Pessoa and the Book of Disquiet are a collaborative construction of editors, publishers, critics, readers, and the wider academic and economic networks responsible for reproducing cultural and literary capital. $^{6}$

6. The long and convoluted editorial history of Pessoa's works - most of which have been posthumously published since the 1940s until now - has been recently summarized by Pizarro (2012, 29-92). However, the detailed social history of the production of Pessoa and the Book of Disquiet has yet to be told. Signs of ongoing struggles for defining text and structure of the Book of Disquiet are 
Through the encoding of authorial and editorial witnesses users of the archive will examine not only Pessoa's writing process - by looking at revision acts represented as layers in the visualization of the transcriptions - , but also the reading and interpretative processes through which the four critical editors give form and structure to Pessoa's planned book. The autograph documentary basis of the digital archive will thus be placed in a dynamic relation with the editors' conjectural organization of textual wholes from Pessoa's archive of fragments. From this multilayered and shifting perspective - from document to text to book relations - users of the $L d o D$ Digital Archive will be able to perceive the fragmentary kinetics of writing as a textual and structural feature of the Book of Disquiet whose variable authorial and editorial forms present us with a work in progress that remains in progress.

\section{Acknowledgements}

"No Problem Has a Solution: A Digital Archive of the Book of Disquiet" is a research project of the Center for Portuguese Literature at the University of Coimbra (2012-2015), funded by FCT (Foundation for Science and Technology). Principal investigator: Manuel Portela. Reference: PTDC/ CLE-LLI/118713/2010. Co-funded by FEDER (European Regional Development Fund), through Axis 1 of the Operational Competitiveness Program (POFC) of the National Strategic Framework (QREN). COMPETE: FCOMP-01-0124-FEDER-019715.

more or less evident in each of the editorial prefaces. The fact that there have been two teams in competition to produce his complete works, in critical editions using different criteria (see, for instance, Castro 1993), reflects not only academic struggles for power over Pessoa's texts, but also market competition among publishers. A particularly significant moment in this history happened when copyright was extended from 50 to 70 years after the death of the author. Pessoa's works were in the public domain for a few years after 1985, but they were repossessed by a major publisher when the new copyright law came into force in the early 1990s. Only in 2005 Pessoa's works fell again in the public domain, but each new textual organization generates its own exclusive rights for publishers and editors. During the last decade, a new generation of scholars has been editing and releasing unpublished texts and inventing all sorts of new books by Pessoa, in a frenzy of editorial activity that cannot be explained without taking into account the institutional and economic competition in the academic and literary markets. 


\section{Works Cited}

Castro, Ivo. 1993. "Intenções finais e mais intenções”. Defesa da Edição Crítica de Fernando Pessoa. Edited by Cleonice Berardinelli and Ivo Castro, 35-99. Lisboa: published by the authors.

Dedner, Burghard. 2006. "Editing Fragments as Fragments". Text 16: 97-111.

Elias, Camelia. 2004. The Fragment: Towards a History and Poetics of a Performative Genre. London: Peter Lang.

Van Hulle, Dirk. 2013. "The Stuff of Fiction: Digital Editing, Multiple Drafts and the Extended Mind". Textual Cultures 8.1: 23-37.

Pessoa, Fernando. 1982. Livro do Desassossego. Edited by Jacinto do Prado Coelho. Lisboa: Ática [2 volumes].

- 2002. The Book of Disquiet. Edited and translated by Richard ZENith. London: Penguin Books.

- 2008. Livro do Desassossego. Edited by Teresa Sobral Cunh a. Lisboa: Relógio d'Água.

- 2010. Livro do Desasocego. Edited by Jerónimo Pizarro. Lisboa: Imprensa Nacional-Casa da Moeda [2 volumes].

—. 2012. Livro do Desassossego. Edited by Richard Zenith. Lisboa: Assírio \& Alvim.

— 2015. Livro(s) do Desassossego. Edited by Teresa Rita Lopes. São Paulo: Global Editora.

Pizarro, Jerónimo. 2012. La Mediación Editorial: Sobre la Vida Póstuma de lo Escrito. Madrid: Iberoamericana Editorial Vervuert.

Portela, Manuel. 2013. "Nenhum Problema Tem Solução: Um Arquivo Digital do Livro do Desassossego". MatLit 1.1: 9-33. http://iduc.uc.pt/index.php/matlit/article/ view/1618

Portela, Manuel and António Rito Silva. 2014. "A Model for a Virtual LdoD”. Literary and Linguistic Computing, March 5, 2014 [Advance Online Publication]. DOI: http://dx.doi.org/10.1093/llc/fqu004

Portela, Manuel and António Rito Silva. 2015. "A Dinâmica entre Arquivo e Edição no Arquivo LdoD”. Colóquio Letras 188: 33-47.

Serúlveda, Pedro. 2013. "Listas do Desassossego". MatLit, 1.1: 35-55. http://iduc. uc.pt/index.php/matlit/article/view/1616/html 